\begin{abstract}
Iranica
Abstracta Iranica Revue bibliographique pour le domaine irano-aryen

Volume 37-38-39 | 2018

Comptes rendus des publications de 2014-2016
\end{abstract}

\title{
Juliane von Fircks, Regula Schorta (eds.). Oriental Silks in Medieval Europe
}

Yuka Kadoi

\section{(2) OpenEdition}

Electronic version

URL: http://journals.openedition.org/abstractairanica/43114

DOI: 10.4000/abstractairanica.43114

ISBN: 1961-960X

ISSN: 1961-960X

Publisher:

CNRS (UMR 7528 Mondes iraniens et indiens), Éditions de l'IFRI

Electronic reference

Yuka Kadoi, « Juliane von Fircks, Regula Schorta (eds.). Oriental Silks in Medieval Europe », Abstracta Iranica [Online], Volume 37-38-39 | 2018, document 8, Online since 30 December 2018, connection on 10 December 2020. URL : http://journals.openedition.org/abstractairanica/43114 ; DOI : https:// doi.org/10.4000/abstractairanica.43114

This text was automatically generated on 10 December 2020 .

Tous droits réservés 


\title{
Juliane von Fircks, Regula Schorta (eds.). Oriental Silks in Medieval
} Europe

\author{
Yuka Kadoi
}

\section{REFERENCES}

Juliane von Fircks, Regula Schorta (eds.). Oriental Silks in Medieval Europe. Riggisberg: Abegg-Stiftung, 2016, 372 p., +227 ill., (Riggisberger Berichte 21), ISBN:

978-3-905014-62-4

1 This volume is a collection of papers given to the international colloquium, "Oriental Silks in Medieval Europe," a scholarly forum which was held in 2011 at the AbeggStiftung, one of the leading textile research centres in Europe. Although it intends to be published as part of the series of the conference proceedings, known as Riggisberger Berichte, Oriental Silks in Medieval Europe comes out as a solid scholarly volume, written by more than twenty renowned textile experts, as well as art and cultural historians with diverse backgrounds. With a long list of references (pp. 345-374), each chapter is richly illustrated with many colour pictures and digitally constructed pattern drawings. As the book title suggests, the main scope of this volume is to contextualise medieval textiles that originally came from the Middle East, Central Asia and East Asia and eventually found their way to European church treasuries and museum collections. Most of the papers published in this volume are nonetheless concerned with the textile arts of the Persian world, in particular those attributed to the time of the Mongol empire $\left(13^{\text {th }}-14^{\text {th }}\right.$ centuries $)$ or specifically to the Ilkhanid period: David Jacoby, "Oriental silks at the time of the Mongols: patterns of trade and distribution in the West" (pp. 92-123); Joyce Denney, "Elite Mongol dress of the Yuan dynasty (1271-1368): focusing on textiles woven with gold" (pp. 124-135); Caroline Vogt, "Mongol splendour: a cloth-of-gold garment in the Abegg-Stiftung collection" (pp. 136-152); Zvezdana Dode, "The ritual dismemberment of a sacred textile: interpreting a Christian embroidery 
found in a nomad burial of the thirteenth or fourteenth century of the Kalmyk steppe" (pp. 153-163); Felicitas Schmieder, "Colourful, but were they seen by European eyewitnesses? Observations on clothing of foreign peoples on medieval world maps" (pp. 164-171); Maria Ludovica Rosati, “'De Opere Curioso Minuto': the vestments of Benedict XI in Perugia and the fourteenth-century perceptions of "panni tartarici" (pp. 172-183); Katja Schmitz-von Ledebur, “'Eyn ander Braun Rok mit swarczen Adelarn': reflections on the eagle dalmatic of the coronation regalia of the Holy Roman Empire and its Chinese silk damask" (pp. 184-194); Evelin Wetter, "Perceptions of Oriental silks at the court of the Bohemian kings during the fourteenth century" (pp. 195-212); Markus Ritter, "Cloth of gold from West Asia in a late medieval European context: the Abū Sa'îd textile in Vienna - princely funeral, and cultural transfer" (pp. 231-251); Nicole Cartier, "The cloth-of-gold chasuble of the chapter of St. Aldegonde in Maubeuge" (pp. 252-265); Juliane von Fircks, "Islamic striped brocades in Europe: the 'Heinrichsgewänder' in Regensburg from a transcultural perspective" (pp. 266-287); Birgitt Borkopp-Restle, "Striped golden brocades with Arabic inscriptions in the textile treasure of St. Mary's church in Danzig/Gdańsk" (pp. 288-299); Michael Peter, "A head start through technology: early Oriental velvets and the West" (pp.300-315). Each contribution deserves to be read in detail, yet as a whole this volume serves as a sequel to the pioneering investigation of so-called "Tartar cloths (panni tartarici)", undertaken by Anne E. Wardwell in the 1980s-1990s. It is thus recommended to be viewed in parallel with Wardwell's works, such as her article published in the volume three of Islamic Art (1988-9), entitled "Panni tartarici: eastern Islamic silks woven with gold and silver (13th and 14th centuries)", so as to overview the scholarly development of this field of research over the past thirty years.

\section{AUTHORS}

\section{YUKA KADOI}

University of Edinburgh 